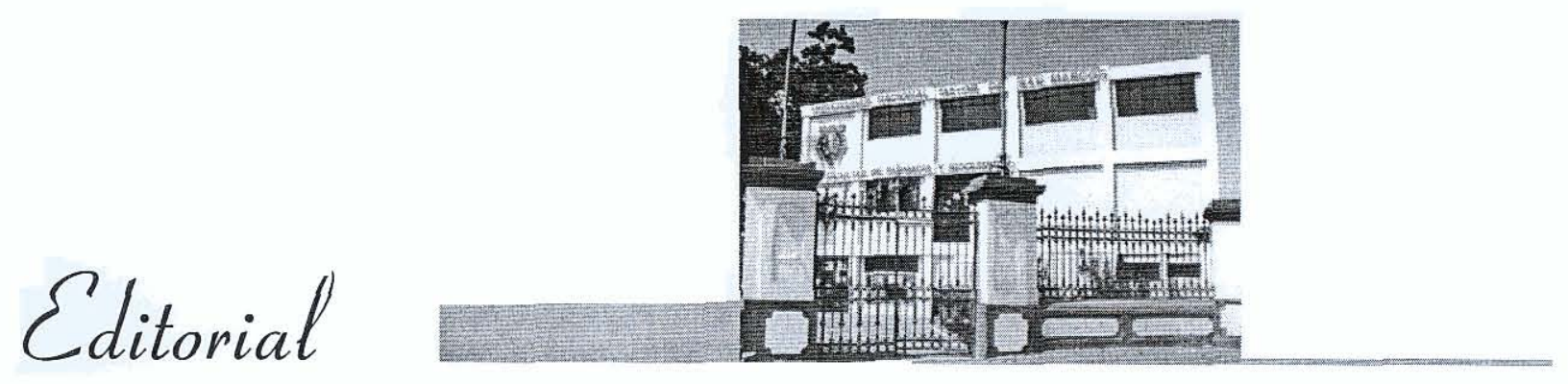

\title{
LA DERMOFARMACIA
}

En los tiempos actuales, es bastante difícil establecer una línea de separación neta entre lo que es una forma farmacéutica de empleo dermatológico y lo que es un «cosmético». Esto se debe a los grandes avances de las ciencias biomédicas y biofarmacéuticas, al mejor conocimiento de la estructura de la piel, así como de sus múltiples e importantes funciones; así mismo, el concepto de cosmético y belleza ha variado profundamente y en consecuencia la formulación. Antiguamente, quizás hasta hace 20 ó 30 años, la función de los cosméticos era puramente decorativa, y la belleza se juzgaba básicamente por el aspecto externo de la piel. Desde tiempos inmemorables, las bellezas que aparecen en las pinturas antiguas, las imágenes de la virgen y los ángeles todos eran blancos y rozagantes; al presente la belleza es sinónimo de buena salud, de cuidados e higiene adecuados, dando lugar a que los cosméticos tengan cierto grado de actividad farmacológica que se manifiesta en los preparados destinados a humectar, hidratar, decolorar, suavizar y lubricar la piel, impartiendo ciertas modificaciones que hacen que en algunos casos se les considere como preparados de empleo dermatológico.

Todos estos hechos han dado lugar al advenimiento de la Dermofarmacia que se define como la parte de la farmacología que estudia todos los aspectos de la formulación, preparación y empleo de los productos destinados al cuidado de la piel, ya sea en estado normal o en el tratamiento de los procesos patológicos.

La Dermofarmacia actualmente constituye un área de especialización en los programas de la Facultad de Farmacia y Bioquímica donde periódicamente se ofrecerán cursos de Post Grado, los que tienen gran aceptación entre los colegas que laboran en las industrias farmacéutica y cosmética, constituyendo una actividad novedosa y rentable. Estamos seguros que muy pronto se implementará la Maestría en Dermofarmacia, ya que esta área de las Ciencias Farmaceúticas está en constante desarrollo. 